\title{
Process features of neutralization of technical sulfuric acid with natural limestone
}

\author{
(C) Sergey A. Vzorodov, ${ }^{*}$ and Anton M. Klyushnikov ${ }^{+}$ \\ Laboratory of Hydrometallurgy. JSC Uralmekhanobr (UMMC-Holding Corp.). Khokhryakov St., 87. \\ Ekaterinburg,620144.Russia.Phone:+7 (343) 344-27-42.E-mail:klyushnikov_am@umbr.ru
}

\section{*Supervising author; ${ }^{+}$Corresponding author}

Keyword: sulfur dioxide, limestone, sulfuric acid, neutralization, gypsum.

\begin{abstract}
The work was devoted to the solution of the environmental problem associated with the disposal of sulfur dioxide emissions from metallurgical production at the Nadezhda Metallurgical Plant (Norilsk, Norilsk Nickel PJSC). For utilization of sulfur dioxide it is planned to build a sulfuric acid plant. Concentrated sulfuric acid produced at plant is planned to be neutralized with natural limestone. This work presents the results of the study on the neutralization of concentrated sulfuric acid with limestone pulp from the Mokulay deposit (Norilsk). The influence of the following parameters was investigated: limestone consumption, acid dosing rate, limestone pulp density. It is established that the process is limited by the internal diffusion of acid through the layer of gypsum. In order to eliminate internal diffusion process it is advisable to carry out neutralization in a periodic mode by introducing a strictly measured amount of acid into an excess amount of limestone pulp. This process allows one to speed up the process of neutralization in 3-3.5 times and achieve a higher value of the final $\mathrm{pH}$ of the pulp comparing with continuous process. Carrying out the process in the periodic way also makes it possible to achieve the complete absence of the release of acidic off-gas during neutralization. The optimal values of neutralization parameters were determined as the following: limestone pulp density was $11-12 \%$, acid delivery time was 40 minutes, neutralization time was 20 minutes, and final $\mathrm{pH}$ value was at least 6.5 , while the limestone feeding was an excessive by $22-28 \%$ from stoichiometry. It was shown that an increase in the limestone pulp density is impractical because it will lead to an increase in the duration of neutralization, as well as to a sharp increase in the viscosity of the gypsum pulp. That, in its turn, makes gypsum pulp difficult to flow from the neutralization apparatus. It was recommended to filter the resulting pulp in order to obtain a gypsum cake with a moisture content of about $55 \%$. It was recommended to store cake on a special site. A flowsheet has been developed and process schedules have been implemented for the design of a neutralization plant with a capacity of up to 2 million tons technical sulfuric acid per year.
\end{abstract}

\section{References}

[1] O.I. Platonov, L.S. Tsemekhman. Methods of sulfur production from metallurgical gases: General and particular issues of different technologies. Non-ferrous Metals. 2009. No.8. P.47-52. (russian)

[2] Y.V. Vasilyev, O.V. Zotikov, O.I. Platonov, L.S. Tsemekhman. Achievements and problems of industrial technology of sulfur production from metallurgical sulfur dioxide. Non-ferrous Metals. 2015. No.1. P.1823. (russian)

[3] L.R. Baraeva,R.T. Akhmetova, P.A. Chudina, A.I. Tuktarova. Study of refinery possibility with the sulfur disposal. Butlerov Communications. 2017. Vol.49. No1. P.121-127. DOI: 10.37952/ROI-jbc01/17-49-1-121

[4] I.A. Massalimov, B.S. Akhmetshin, A.N. Khusainov. Structural and thermodynamic characteristics of mechanically treated sulfur. Butlerov Communications. 2017. Vol.50. No.6. P.56-60. DOI: 10.37952/ROI-jbc-01/17-50-6-56

[5] E.V. Prokudina, D.L. Tropnikov, A.V. Karataeva, O.V. Shukshina. The neutralization of technical sulfuric acid with natural limestone at JSC Svyatogor. Mountain News and Analysis Bulletin. 2016. No.8. P.340-345. (russian)

[6] G.M. Voldman, A.N. Zelikman. The theory of hydrometallurgical processes. Textbook for high schools. Moscow: Intermet Engineering. 2003. 464p. (russian)

[7] S.G. Komlev. Technological calculations in mineral processing. Equipment selection. Yekaterinburg: USMU. 2007. 57p. (russian) 
PROCESS FEATURES OF NEUTRALIZATION OF TECHNICAL SULFURIC ACID WITH NATURAL LIMESTONE 110-118

[8] A.G. Kasatkin. Basic processes and apparatuses of chemical technology. Textbook for high schools. Moscow: JSC "Alliance". 2004.753p. (russian)

[9] R.R. Daminev, L.R. Asfandiyarova, R.R. Nasyrov, G.V. Yunusova. Application of flocculants for wastewater treatment of chemical industry. Butlerov Communications. 2015. Vol.43. No.7. P.117-121. DOI: $10.37952 /$ ROI-jbc-01/15-43-7-117 